\title{
A New Occurrence of (Gold-Bearing) Graphite in the Assosa Region, Benishangul-Gumuz State, W Ethiopia
}

\author{
Liam A. Bullock ${ }^{1,2}$ and Owen J. Morgan ${ }^{2}$ \\ 1. School of Geosciences, University of Aberdeen, Aberdeen, AB24 3UE, United Kingdom \\ 2. Tactical Environmental Response, Yorkshire, LS29 9BZ, United Kingdom
}

\begin{abstract}
The Assosa region of western Ethiopia hosts newly discovered and potentially highly economic graphite-bearing schist units. Due to its unique physical and chemical properties, graphite is quickly becoming an increasingly important economic resource. Graphite occurs over much of the area, and is hosted predominantly by quartz-graphitic schist, quartz-feldspar-mica schist and quartzite. The quartz-graphitic schist covers an area of $37 \mathrm{~km}^{2}$, forming steep valleys and ridges across a $190 \mathrm{~km}$ long belt. Graphite is texturally-variable within and across units. Crystal habit varies from highly crystalline to irregular flakes. Flake sizes range from amorphous and crystalline small flake to coarse large flake $(>150 \mu \mathrm{m})$, with beneficiation of $\sim 70 \%$ and yield potential of $>95 \%$ (froth flotation methods). The license area is already a well-known gold-hosting area, and potentially economic gold deposits occur within the graphite-bearing units. Overall, the site shows excellent geochemical indicators, field observations and historical accounts of high gold content. It is suggested that textural variations may be the product of (1) early in-situ formation during (early- to late-Proterozoic) prograde metamorphism and (2) later vein-type mineralization during retrograde metamorphism. The discovery of graphite in western Ethiopia is the first documented and preliminary studies suggest a high economic potential for the deposits.
\end{abstract}

Key words: Graphite, gold, metamorphism, X-ray fluorescence, X-ray diffraction.

\section{Introduction}

Since 2011, Ethiopia-based exploration company GP Resource Mining PLC (GPRM) has been carrying out detailed exploration on its concession in Ethiopia. The main role of the exploration programme was to identify gold and other economic mineral deposits. During this ongoing exploration, a number of new and extensive graphite-bearing deposits have also been identified. Due to increasing global demand and economic importance, the discovery of a new graphite occurrence is significant. Formation of graphite is known as "graphitization", i.e., in-situ (regional and/or contact) metamorphism of organic matter. Graphite may also form epigenetically, in veins or as an overgrowth on pre-existing graphite [1-4]. Graphite may form from low to medium grade facies (e.g., greenschist facies) as well as at higher grade granulite

Corresponding author: Liam A. Bullock, research fellow, research fields: geology, petrology and geochemistry. facies conditions. Graphitization denotes the transformation of carbonaceous debris to amorphous or crystalline graphite (perfection of crystallinity increasing with grade of metamorphism [5-8]). Under metamorphic conditions, graphite forms above $400{ }^{\circ} \mathrm{C}$ [7], though typical conditions under which flake graphite may form up to $750{ }^{\circ} \mathrm{C}$ and 5 kilobars [3]. Transformation from disorientated debris to organized layers in the triperiodic graphitic structure is achieved through microtextural, structural and chemical modifications, relating to composition and organization of the original material [8-10]. Carbonaceous material is a common constituent of meta-sedimentary rocks, such as those found in the Assosa study area.

Natural graphite is classified as flake or microcrystalline graphite, macrocrystalline graphite, and vein or lump graphite, based on its underlying physical and chemical properties [11]. 

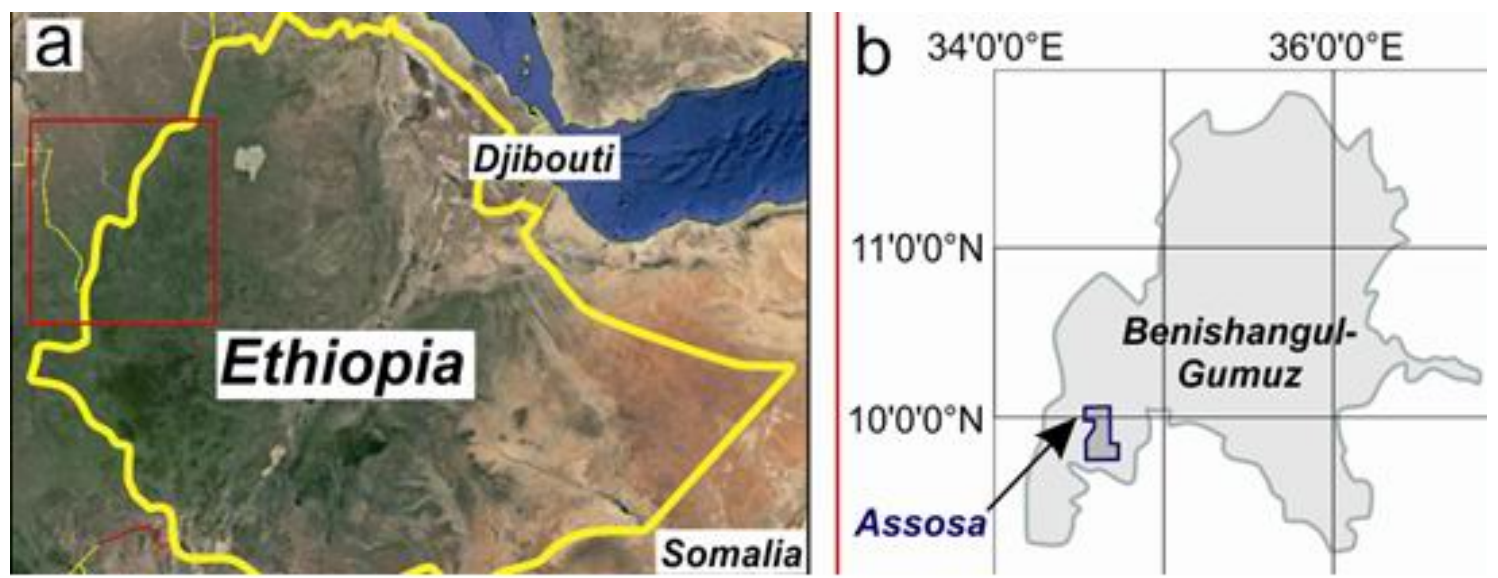

Fig. 1 (a) Landsat image of Ethiopia (from Google Earth), with Benishangul-Gumuz state located within the red box in the west of Ethiopia; (b) location of the Assosa study region (indicated by the purple outline) in the state of Beshangul-Gumuz.

Graphite was recently discovered by GPRM near the town of Assosa in the Benishangul-Gumuz region of western Ethiopia (Fig. 1) as part of an extensive quartz graphitic-schist unit. The importance and extent of the graphite, coupled with the known occurrence of gold in area, makes this a potentially prosperous resource.

Graphite is now acknowledged as a key strategic mineral globally due to its rarity, unique chemical composition, and physical characteristics, meaning that graphite cannot be substituted for any other mineral or material [11]. This has led to graphite being a dominant requirement for the world's high technology applications. Graphite has a number of key chemical and physical properties that make it economically important material for electrical and technological industries. These include a high melting temperature, stability and strength, high thermal conductivity, high electrical conductivity, chemically inert, high resistance to thermal shock, electrical conductor, ability to absorb radio waves, a high radiation emissivity, high compression strength, resistant to corrosion and chemical attack, power to bulk neutron absorption, high ratio of thermal neutron scattering, and a flame retardant nature [12]. These properties, combined with the rarity of the material, mean that high-quality flake graphite (particularly with high carbon content) is highly sought and used for high technology applications and green energy initiatives.

Flake graphite is used for the vastly expanding touch screen tablet technologies and manufacturing. Graphite is also used in lithium-ion batteries and carbon-based applications, and demand is set to rise $[13,14]$ with the need for green energy and fuel cell technology. The world reserves of graphite are estimated at $77 \mathrm{Mt}$ (as of 2011), with the largest known reserves in China $(55 \mathrm{Mt})$ and India $(11 \mathrm{Mt})$ [13]. World production of graphite (in 2011) was $925,000 \mathrm{t}$, with China as the largest producer $(600,000$ t), followed by India (140,000 t) and Brazil (76,000 t) [14]. Global demand for flake graphite has increased by $40 \%$ in the past 5 years [13]. African graphite is particularly world renowned for its large and high purity flake, yielding high prices [15]. Known production of graphite in Africa is confined to Madagascar, Mozambique, Namibia and Tanzania. Chinese, Japanese, Indian, South Korean and North American markets currently dominate the need of increase for graphite. Research by the University of California predicts that, by $2030,64 \%$ of all US-made cars will be electric, which means exponential growth for graphite [16]. The USA currently has no crystalline flake graphite production.

This study provides the first detailed findings and characteristics of the graphite occurrence in the 
Assosa region of Ethiopia in terms of petrology, geochemistry and geology. The geochemical results also highlight the potential for gold as an accompanying mineral resource in graphite-bearing units. The characterization is based on field and microscopic observations, geochemistry (atomic absorption spectroscopy and X-ray fluorescence), and laboratory investigations (flotation experiments and X-ray diffraction methods). Though the main aim of this paper is to document the graphite occurrence in the Assosa region, geochemical analysis has also been undertaken to better quantify gold $(\mathrm{Au})$ in the sampled units, due to the potential economic importance of gold in the area.

Observed textural variations within and across lithological units may be the product of variable formation conditions, including (1) in-situ crystallization during prograde metamorphism, and (2) vein-type mineralization during retrograde metamorphism. The findings provide important information for knowledge, planning and economic potential of graphite in western Ethiopia, as well as the potential for resourceful gold occurrence in the area. These initial results will also allow for more detailed consideration of formation and economic potential of graphite in the Assosa region of Ethiopia.

\section{Geological Setting}

\subsection{General Geological Setting}

The Assosa study region (licensed to GPRM as of 2014/15) is located in the state of Benishangul-Gumuz in western Ethiopia (Figs. 1-3). The region straddles the border between the Ethiopian highlands and South Sudan. The total size of the study area is $412 \mathrm{~km}^{2}$, extending north-south $\sim 32 \mathrm{~km}$ long by $\sim 13 \mathrm{~km}$ wide. The study area is located within the schist belt of the Western Precambrian Basement Complex rocks of Ethiopia. The study area lies on a major suture zone in the Southern Arabian-Nubian Shield, a Neoproterozoic (Pan-African) Shield Area with oceanic affinity [17]. The zone contains meta-sediments of deep-sea marine sedimentary origin, volcanic in calc-alkaline (island-arc) characteristic and fragments of mafic to ultramafic rocks (ophiolites). The sutures of former oceanic areas that have accreted to form the Arabian-Nubian Shield consist of linear schist belts containing phyllitic to greenschist facies meta-sediments and meta-volcanics [17] (Fig. 2).

The sutures in the accreted shield areas are the loci for major shear zones that are commonly host to gold deposits. Arabian-Nubian Shield mineralization is dominated by orogenic gold and subordinate refractory metals such as tantalum, niobium and tungsten, REEs, uranium and tin. Gold-bearing quartz-carbonate veins are associated with late- to post-tectonic calc-alkaline intrusions emplaced at the end of the Nabitah orogeny (680-650 Ma) [17]. Orogenic gold in veins concentrate in areas of transpressional-shearing, strike-slip faulting and thrusting, as well as at margins and adjacent wall rocks associated with intermediate plutons. Such veins have been mined for over 6,000 years, providing gold to the Egyptian empire.

Graphite is commonly hosted within the schist units in the area (Figs. 2-3). Graphite occurs in the north-western region of the study area (referred to as Area of Interest 1 or "AOI1" due to the potential economic importance; Fig. 3), and is found within a unit classified as the quartz-graphitic schist, as well as in units classified as quartz-feldspar-mica schist, quartzite, amphibolite and pegmatitic-graphitic bodies. The quartz-graphitic schist is found at the western part of the study area, and extends from the north-west to the south-east. It is likely that increasing metamorphic grade beyond amphibolite facies converted coal or carbonaceous material to "amorphous" graphite. Natural flake graphite is considered a granulite facies mineral [3], though it may form at lower grades [3, 7].

\subsection{Structural Controls on Metamorphism}

The sutures of former oceanic areas that have accreted to form the Arabian-Nubian Shield consist of linear "schist belts" containing phyllitic to greenschist 


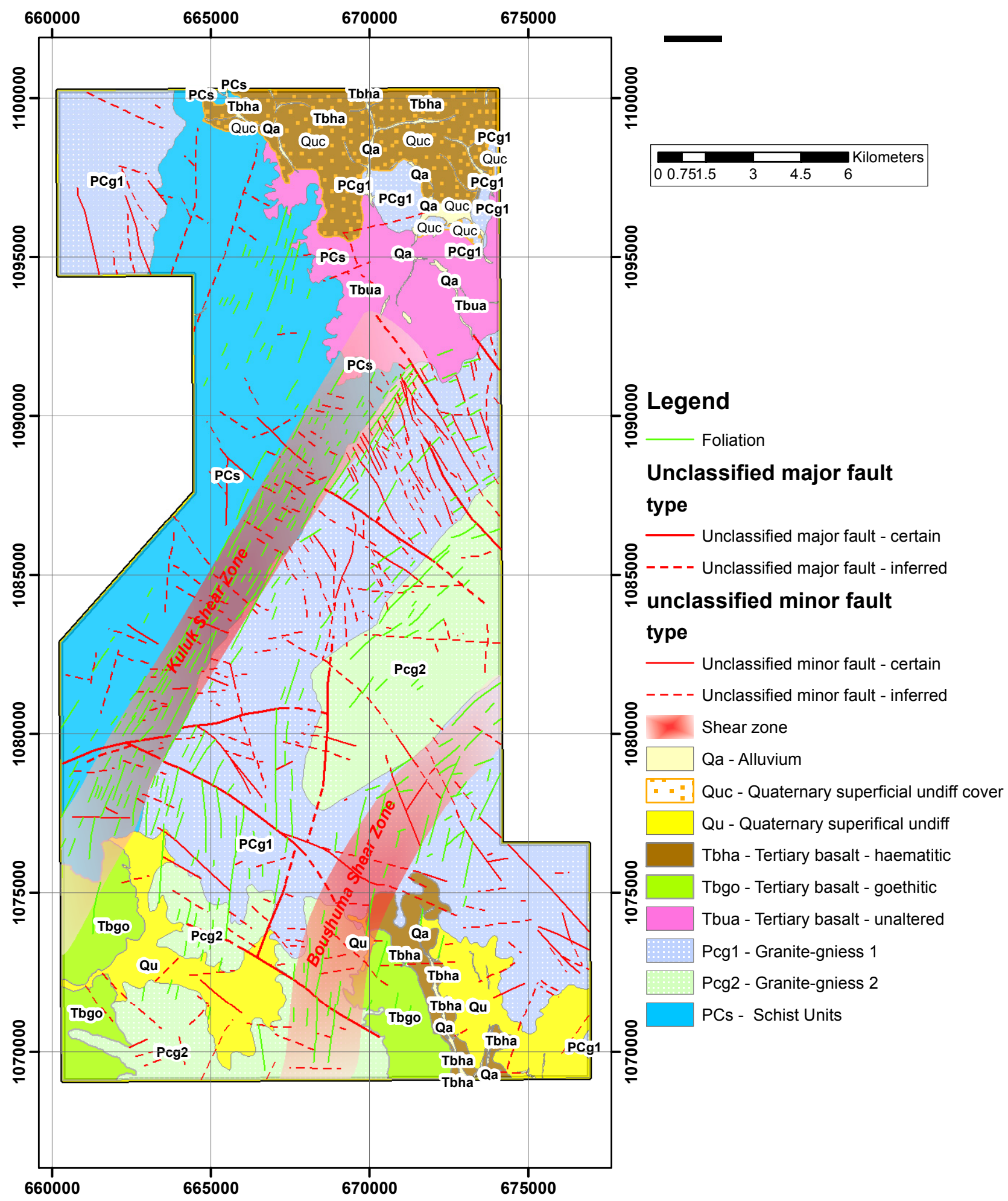

Fig. 2 Generalized (semi-detail) geological map of the Assosa study area. Graphitic units (including the quartz-graphitic schist belt) form part of the schist units (labelled as PCs) in the west of the region. The map also highlights two extensive shear zones across the region (Kuluk and Boushuma shear zones), a number of structural lineations (associated with shearing) and foliations, as well as the occurrence of plutonic and extrusive igneous units, and modern day alluvium. Gold mineralization is commonly associated with the Kuluk and Boushuma shear zones. 
facies meta-sediments and meta-volcanics. The western Ethiopia area, as part of the Pan African Orogenic mobile belt, is characterized by its own tectonic episodes. The volcano-sedimentary lithologies of the western Ethiopia are generally of greenschist and/or lower amphibolite facies metamorphism. These rocks were extensively intruded by dioritic and granitic batholiths and plutons (Fig. 2).

Previous geochemical investigations of this layered sequence indicate that they are of island-arc and plate margin origin. Previous work [18] proposed five major tectonic zones for western Ethiopia, of which three represent low grade volcano-sedimentary belts. The remaining two marginal zones represent high grade gneissic rocks. Other studies [19, 20] detailed the two major litho-tectonic terrains as representative of Precambrian basement rocks of Ethiopia, namely the older Archean age and the younger Pan African terrains. These consist of the N-S trending low grade volcano-sedimentary belts, associated with minor ultramafic units and intrusions, ranging from mafic to granitic composition. The volcano-sedimentary sequences are generally developed $\sim 1,000-500 \mathrm{Ma}$, and the major tectonic features responsible for metamorphism in the area are predominantly early- to late-Proterozoic in age [21].

The study area is found within the Sirkole and Daka domains [22, 23]. These consist of alternating gneiss and volcano-sedimentary sequences, interpreted as an imbricated basement-cover thrust-nappe complex. All the domains are intruded by syn- and post-kinematic Neoproterozoic granitoids. Structural analysis within the Sirkole and Daka domains indicates the presence of pre-Pan African structures, upon which Neoproterozoic deformation has been superimposed. The gneissic rocks of these two domains are regarded as pre-Pan African continental fragments amalgamated to West Gondwana during Neoproterozoic collision events. Unconformably overlying the entire aforementioned sequence are a series of tilted but internally undeformed conglomerate-sandstone-shale sequences, regarded as post-accretionary molasse-type deposits, formed during gravitational collapse of the Tuludimtu Belt. The Tuludimtu Belt is interpreted as a collision orogenic belt formed during the assembly of West Gondwana prior to final closure of the Mozambique Ocean. Contacts between the above domains are not always exposed, but shear zones with high strain fabrics are found (such as the Kuluk and Boushuma shear zones highlighted in Fig. 2). Consequently, contacts are interpreted in all cases to be tectonic. The contact between the Meta-granitoids and meta-volcanic is tectonic (NE-SW striking Kuluk Shear Zone; Fig. 2) [22, 23].

The regional structural set-up of the Western Ethiopian shield is represented by three phases of deformation (D1-D3), associated foliations ( $S 0-S 1)$, folds $(F 1-F 2)$ and lineations $(L)$. The western part of this shield is represented by the N-S striking Assosa-Kurmuk belt, while the eastern part is marked by the N-S striking TDB (Tulu Dimtu Belt), cut by the NW-SE striking DSZ (Dedessa Shear Zone). The structural set up of the study area is restricted to certain localities exhibiting $D 1$ and $D 3$ phases of deformation and widely recognized regional $D 2$ deformation. $D 1$ is the oldest phase of deformation, observed within gneisses in the southeastern and southern parts of the study area. Phase D2 is NE-SW striking, and affected all units with the exception of post-tectonic granites and Tertiary basalts. Phase D2 also formed synforms and antiforms in the northern part of the area, and is associated with mega-shear zones. Phase $D 3$ represents a brittle ductile phase of deformation, trending NW-SE, and manifests as lineaments, associated quartz veins and veinlets.

\subsection{Mineralization and Alteration}

Arabian-Nubian Shield mineralization is dominated by orogenic gold and subordinate refractory metals such as tantalum, niobium and tungsten, REEs (rare earth elements), uranium and tin. Gold-bearing quartz-carbonate veins are associated with late- to 
post-tectonic calc-alkaline intrusions, emplaced at the end of the Nabitah orogeny ( 680-650 Ma) [17, 22, 23].

Orogenic gold in veins concentrate in areas of transpressional shearing, strike-slip faulting and thrusting, as well as at margins and adjacent wall rocks associated with intermediate plutons. Mineralizations such as pyrite, chalcopyrite, magnetite, rutile and ilmenite are observed in quartz veins/veinlets and some altered rock units such as amphibolite schist, quartzo-feldspathic sericite schist and granitic gneiss. Mineralization often follows structures such as brecciation, fractures and shear zones.

Alteration in the study area is characterized by widespread silicification, sericitization, chloritization, limonitization, epidotization, carbonitization, kaolinization and ferruginization. Silicification is mostly observed in quartz veins, veinlets and stringers. Silicified granitic gneiss and amphibolite schists are found to contain mineralization of sulfides and oxides. Similarly, sericitization, carbonitization, chloritization, and limonitization are found within these rock units. Such alteration is most commonly observed in quartzo-feldspathic sericite schist units, associated with sulphide mineralization of cubic pyrite, chalcopyrite, rutile and ilmenite. Limonitization alteration is common in vugges and cavities of quartz veins. Ferruginization alteration is common in brecciated units and lateritic rocks. Silification is indicated by discordant quartz-tourmaline veins observed in Lower Koncha and Yohotse River valley, crossing the sheared granites and greenschist units respectively.

Such alteration is recognized to be associated with $D 2$ phase of deformation. Moreover, perpendicular to $D 2$, quartz vein-filled joints are seen in the greenschist units outcropping in the western side of the Kuluk River. Granitic gneiss is observed to be altered by silicification, sulfidation and oxidation, filling E-W joints and N-S foliations. The joint-filled quartz and quartz-pegmatite veins bear sulfidies such as pyrite, chalcopyrite, sphalerite and galena. Visible gold has been recovered from the joint-filled crushed quartz and pegmatite veins, hosted by granitic gneiss. The gold mineralization in the mapped area is structurally-controlled. Phase D2 is the main deformation that is noted in direct field observations. Gold mineralization in the study area is therefore associated with the activation alterations above.

\section{Methodologies}

\subsection{Sampling}

Extensive sampling was undertaken in the northern section of the study area, particularly within the area classified as AOI1. Sampling also included the southern regions of the study area, though the majority of sampling took place in the north. This is mostly due to a higher current knowledge of the geology of the area in the north, outcrop exposure (including the targeted quartz-graphitic schist and graphite-bearing units), previous artisanal workings in the area, and ease of access.

\subsection{AAS (Atomic Absorption Spectroscopy)}

Geochemical analysis was undertaken in order to better quantify the gold content within samples. Graphitic samples were prior prepared for analyses to 200 mesh, before being analyzed at SGS (Tanzania and Toronto) and ALS (Ireland) for Au. Generally, 100 gram samples were required for analyses, unless not otherwise possible (restrictions relating to recoverable sample amount). The samples were prepared and analyzed for $\mathrm{Au}$ by conventional fire assay-atomic absorption spectrometry (Au-AAS). Despite some analytical limitations (relating to improper fluxing and roasting techniques), Au-AAS is generally regarded as the dependable analytical method for Au [24].

Full sample preparation of rock chip and rock crush was undertaken for Au-AAS, with aqua regia methodologies implemented. Roasting was undertaken before sampling in order to remove the graphite and 


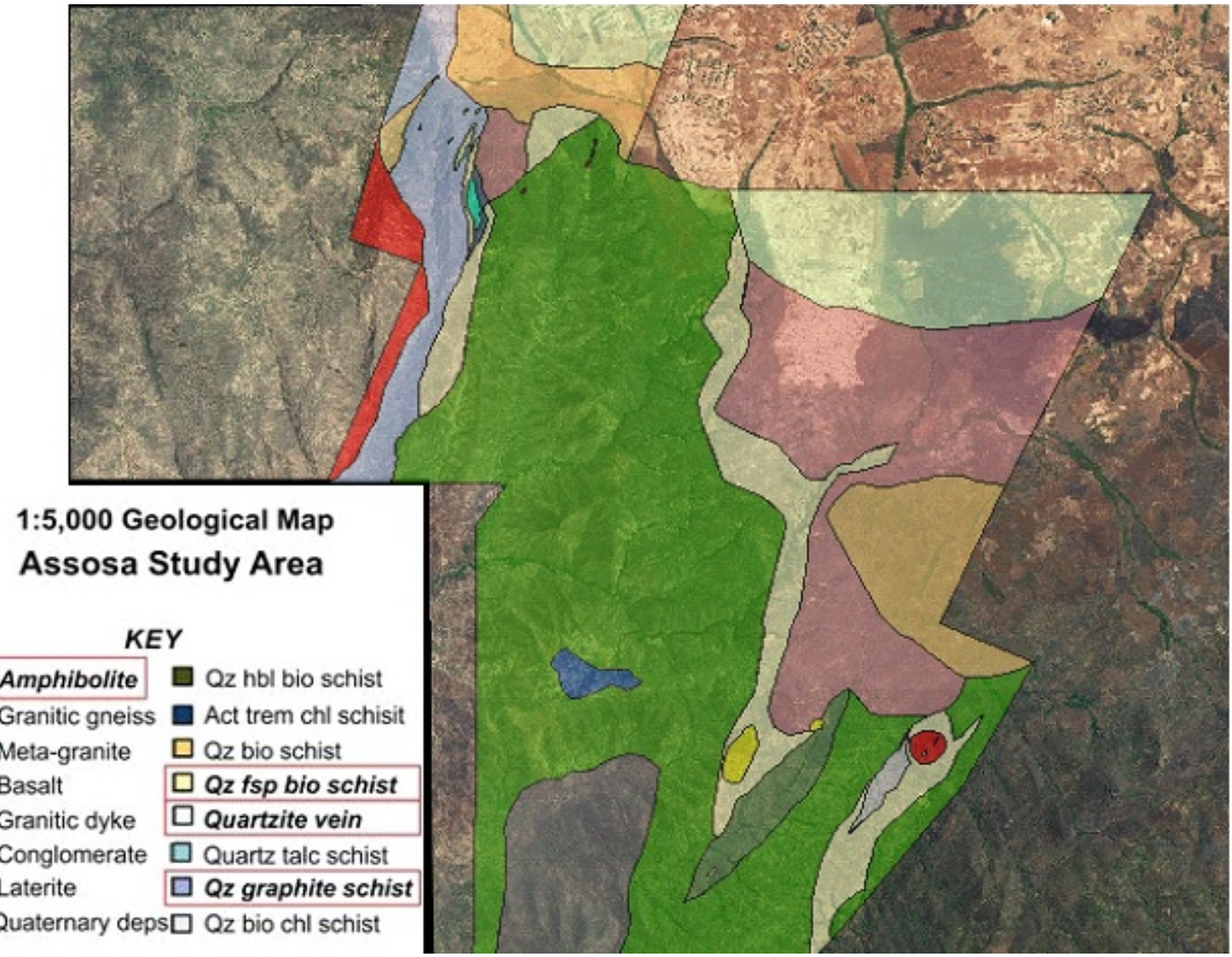

Fig. 3 Detailed 1:5,000 geological map of the northern region of the study area (AOI1), produced by GPRM. Layered Precambrian Afa Domain Rocks are represented by schist units, with younger pre to syn tectonic granites, post tectonic granites, and basalt units. The graphite-bearing units are highlighted in the key. The dominant unit, the quartz-graphitic schist (Qz graphite schist in the key), is identified as the lilac blue unit in the north-western region.

not interfere in the fusion process. The general procedure undertaken is that outlined in previous experimentation [25]. The general method involved mixing of $\sim 50 \mathrm{~g}$ of a powdered sample with sodium carbonate, borax, litharge, flour and silica, with a foil of $\mathrm{Pb}$ or $\mathrm{Ag}$ occasionally added as a collector. The mixture was fired (up to $1,200{ }^{\circ} \mathrm{C}$ ) to create a lead button. The resultant Au was digested using an aqua regia mixture and the solution was analyzed by an atomic absorption spectrometer using $\mathrm{Au}$ standards [25].

\subsection{X-ray Fluorescence}

The Niton XL3t GOLDD+ analyzer (handheld) and FXL portable XRF analyzer (table top) units were used for XRF analysis. Sample preparation included the rock powder being pressed in to compacted pots, and run for 90 seconds (Niton FXL) or 180 seconds (Niton XL3t). For Niton FXL analysis, the sample stage was set to continuously rotate. Samples were placed on the platform in the fixed holding unit, the lid shut, and controls and data were viewed and controlled via NDTr $5.2 \mathrm{x}$ software. Samples were positioned with as much contact as possible to the instrument's surface in order to ensure that the greatest amount of X-rays bombarded the sample, optimizing the count rate and mitigating the effects of irregular sample surface structure on X-ray scatter. A total of ten ROCKLABS certified standards were also analyzed by XRF for accuracy determination and correction. All standards are described as containing feldspar minerals, basalt and iron pyrites, with minor quantities of finely divided Au-containing minerals. Instrument calibration was achieved through comparison of expected and 
produced elemental concentrations of the certified samples. A single standard sample of known geochemistry was run routinely to ensure the stability of the instrument. Standard soil mode is the most efficient mode for samples with the percentage of elements of interest $<1 \%$, the matrix material is light (e.g., aluminum silicate), and where elements with an atomic number greater than iron do not exceed several percent.

There are still a number of concerns that arise from such methodologies relating to precision, accuracy and ability of handheld XRF devices to detect certain elements. One such element of interest to exploration and mining companies is gold. It is therefore worth noting that, due to the uncertainties, portable XRF was used in combination with XRD for the purpose of this study as a means of semi-quantitative and qualitative analysis. However, effective calibration and correction has been applied in order to minimize such uncertainties. A total of ten certified standards were selected for handheld XRF accuracy determination and correction. Standards were selected based on their appropriate nature (i.e., Au reference materials), and the range in $\mathrm{Au}$ results they exhibit (in order to assess the range limitations of the method). Results (Fig. 4 and Table 1) suggest that, with correct calibration and procedure, this unit is capable of determining gold concentrations in a sample in at least a semi-quantitative manner, as supported by comparisons to certified standard values. The method is most effective for samples containing gold content between 5 ppm and 30 ppm (Fig. 4 and Table 1).

\subsection{Flotation and Beneficiation}

Laboratory observations were carried out on a number of weathered graphite sources collected within AOI1; all classified as rock chips. A sample was then taken from each and coarse-ground, followed by ASTM standard wire mesh sieving in order to correctly achieve the liberation size of the flakes from the host rock. Sieve sizes used were $2 \mathrm{~mm}, 1 \mathrm{~mm}, 250$ $\mu \mathrm{m}$ and $125 \mu \mathrm{m}$. Each sieved sample was examined under a microscope in order to observe optimum liberation size. The froth floatation procedure was chosen as the concentration method of the graphite.

Graphite is a naturally hydrophobic mineral and will float. However, in order to separate the graphite concentrate from the quartz, mica, feldspar and other minerals that may be present, additional reagents were used. The sieved sample weighing $30 \mathrm{~g}$ was then placed in vessel containing water and other agents. The vessel was placed on an agitator, a laboratory air stone was inserted and attached to a high blow filtered air pump. Graphite concentrate was collected within the apparatus. This concentrate was then subjected to a second froth flotation to further remove any material that may have smeared during preparation. The final concentrate was then oven dried and placed in a desiccator to cool. The remainder of the sample was collected as middling and tailings.

For column flotation of graphite, the compressed air was blown into the column through the bottom, and a preconditioned feed-slurry added from the feed-inlet after few seconds. The froth column raised and reached to the froth outlet. Wash-water was continuously sprayed from the inlet and the cleaned froth collected in a suitable container from the froth outlet. After collecting the mineralized froth completely, the waste slurry (tailings) containing impurities were withdrawn from the tailings outlet. Again, a fresh batch of feed-slurry was introduced, and the whole procedure repeated. The collected froth was then filtered, dried in an air-oven at $105{ }^{\circ} \mathrm{C}$, weighed accurately and subjected to proximate analysis. This procedure was also adopted for the column tailings.

\subsection{X-ray Diffraction}

The XRD (X-ray diffraction) procedure was undertaken at Keele University (UK). Samples were pre-prepped (crushed and sieved) and coarsely powdered $(\sim 100-125 \mu \mathrm{m})$. Post-ash samples were roasted at $1,000{ }^{\circ} \mathrm{C}$ in an oven prior to XRD analysis. 


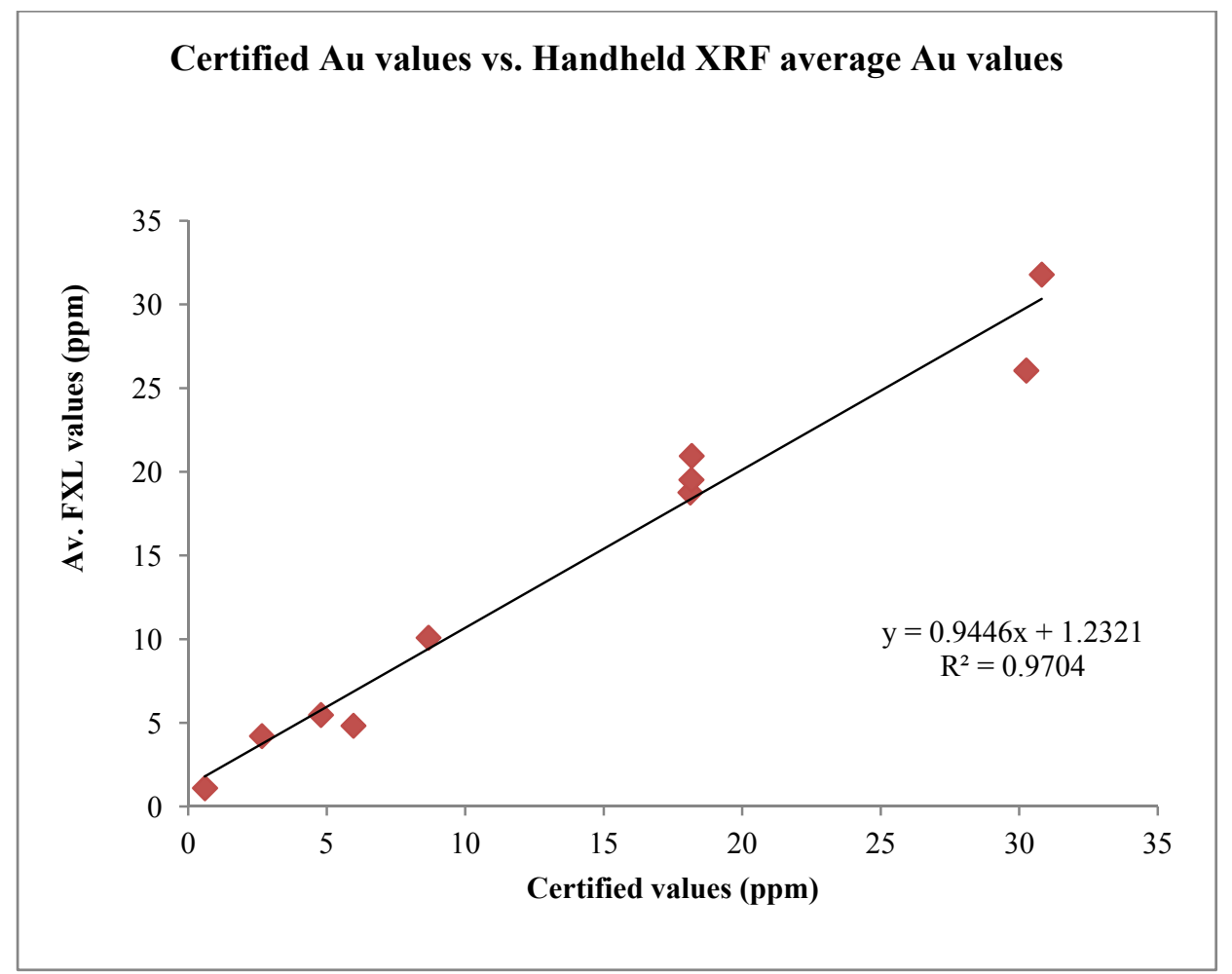

Fig. 4 Comparison between certified standard values (x-axis) and average XRF Au values achieved over a minimum of 50 runs (y-axis). Equation and $r$ value (calculated by Microsoft Excel) also shown. Results indicate that, despite inherent limitations of handheld XRF methods, the procedure is capable of providing qualitative and semi-quantitative results (for use such as a baseline geochemical survey).

Table 1 Summary of results for standard runs (certified ROCKLABS Au standard samples) by XRF Au analysis, including anticipated Au value (based on standard Au-AAS methodologies), average Au content of sample as determined by Niton FXL, the average XRF error, the number of batch runs and a determination of the reliability based on results. Though results are generally favorable, error values are deemed considerable (but consistent, allowing for correction if necessary).

\begin{tabular}{llllll}
\hline $\begin{array}{l}\text { ROCKLABS } \\
\text { certified } \\
\text { standard }\end{array}$ & $\begin{array}{l}\text { Certified Au value } \\
(\mathrm{ppm})\end{array}$ & $\begin{array}{l}\text { Certified Au error } \\
(\mathrm{ppm})\end{array}$ & XRF Au value (ppm) & XRF Au error (ppm) & $\begin{array}{l}\text { Number } \\
\text { of XRF runs }\end{array}$ \\
\hline SP59 & 18.12 & 0.12 & 18.78 & 2.56 & 50 \\
SQ48 & 30.25 & 0.17 & 26.06 & 2.75 & 75 \\
SQ71 & 30.81 & 0.21 & 31.79 & 2.91 & 50 \\
SP72 & 18.16 & 0.1 & 19.54 & 2.62 & 70 \\
SN75 & 8.671 & 0.054 & 10.09 & 2.64 & 80 \\
SE68 & 0.599 & 0.004 & 1.11 & 3.01 & 50 \\
SL76 & 5.96 & 0.052 & 4.83 & 1.95 & 420 \\
SJ80 & 2.656 & 0.016 & 4.22 & 2.83 & 50 \\
PK-2 & 4.785 & 0.129 & 5.48 & 2.41 & 50 \\
SP73 & 18.17 & 0.12 & 20.96 & 2.57 & 50 \\
\hline
\end{tabular}

The coarsely-powdered samples were placed on a flat disk sample holder, gently compressed, and scanned on a Bruker D8 Advance X-ray diffractometer using $\mathrm{CuK} \alpha$ radiation, a scan range from 5 to $90 \mathrm{~nm}(2$ Theta), a $0.03 \mathrm{~nm}$ (2 Theta) step size and a data collection time of $30 \mathrm{~s}$ per step. Results were determined by built-in Bruker software and Bruker EVA software. EVA was used in order to determine phases by peak comparison to pre-determined elements and components (peaks were identified by the software 
and examples overlain on the spectrum).

\section{Field Observations}

Extensive graphite occurrence (Figs. 3, 5-6) is common in the north-western AOI1, typically hosted within quartz-graphitic schists, quartz-feldspar-mica

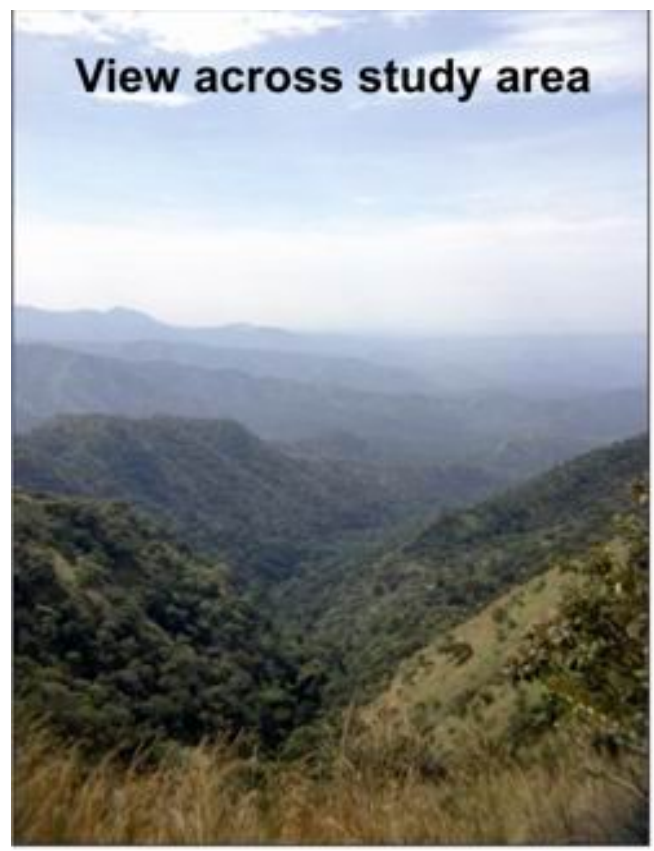

schists, quartzites, amphibolite schists, brecciation zones and pegmatitic-graphite bodies.

The quartz-graphitic schist is found at the western part of the study area, extending from the Korondo stream to west of the Banga stream. The quartz-graphitic schist covers an area of $37 \mathrm{~km}^{2}$, forming steep valleys

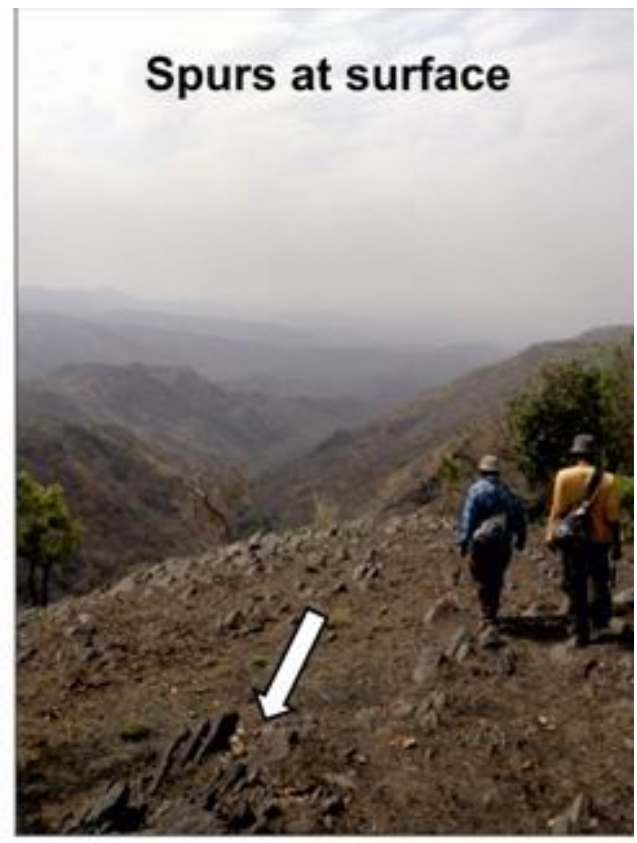

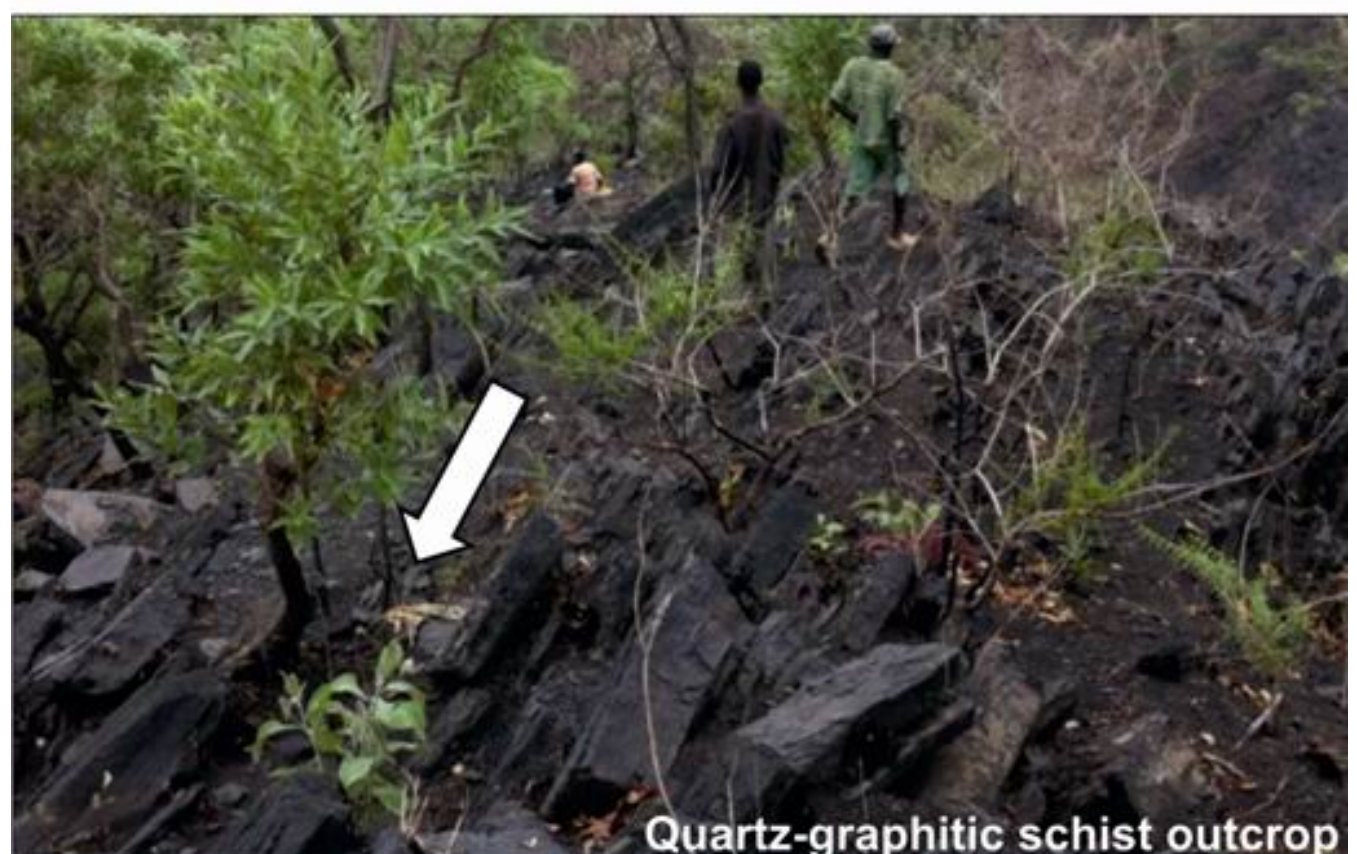

Fig. 5 Field observations of the steeply dipping quartz-graphitic schist unit spurs across the north-western study area (AOI1). Arrows indicate the prevalent dip of the unit; note the steepness of the dip. A dark gray to black color is also evident in fresh and weathered surfaces. 

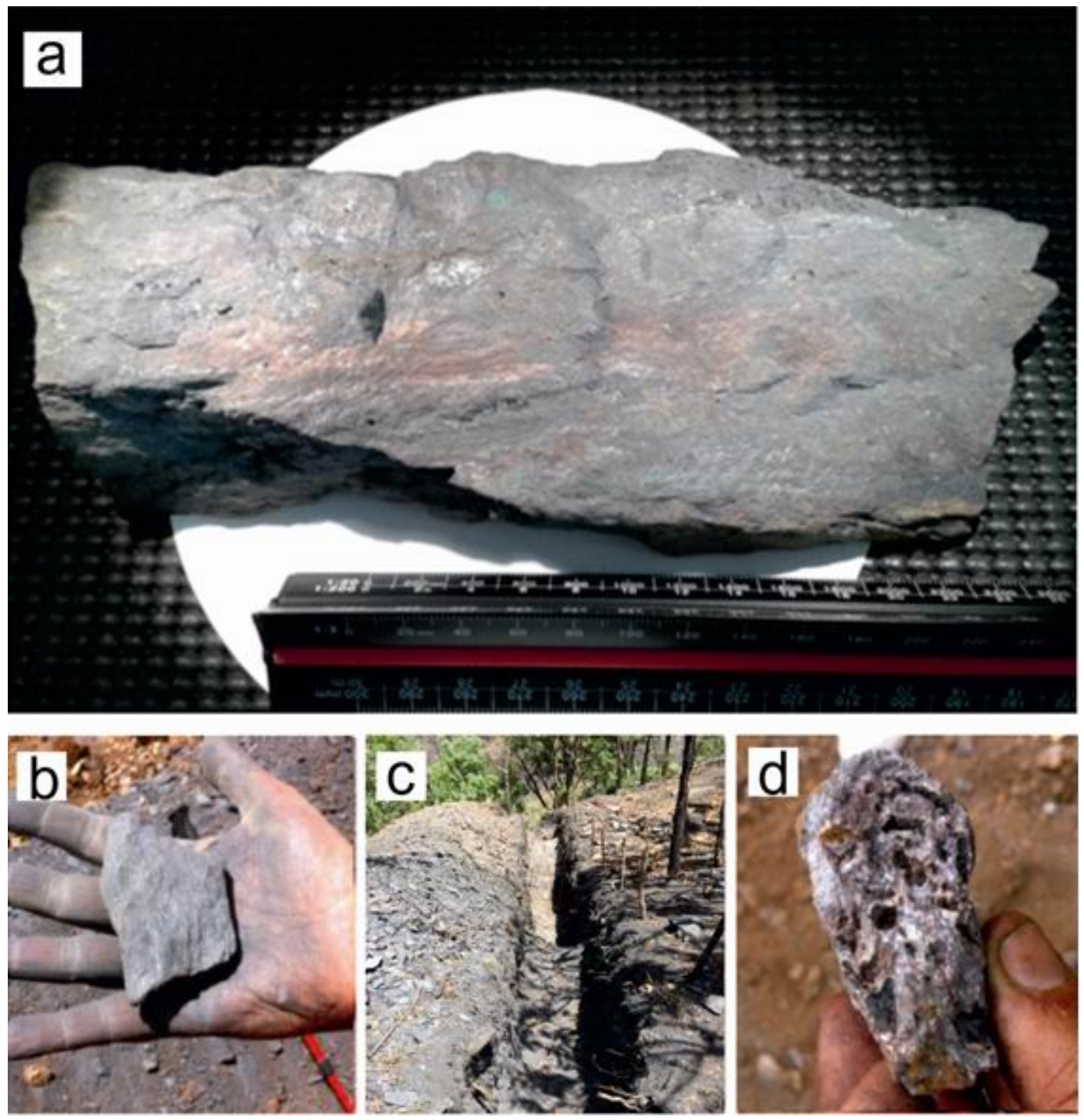

Fig. 6 (a) Hand specimen sample of the (heavily mineralized) quartz-graphitic schist; and (b)-(d) field examples, including (b) a hand specimen showing the high carbonaceous content; (c) outcropping schist (trench excavation) and (d) a serecitic vugge sample.

and ridges. The unit is thus far identified as a long, linear belt, up to $190 \mathrm{~km}$ in length (Fig. 3). The depth of the unit is unknown, and is to be determined in the future by drilling. Based on spur observations (Fig. 5), the unit is potentially $>200 \mathrm{~m}$ thick, making for large tonnage potential. Graphite appears to be a dominant feature on the northwestern study area boundary, running through much of the southerly extent of the study area. A number of spurs have been identified as being graphite hosts and indicated a large tonnage potential for open pit mining. Weathered outcrop and hand specimens are dark-to-dark gray in color, fine in grain size, and are generally composed of quartz, graphite, sericite and some unidentifiable minerals (Fig. 6).

Outcrop units are mostly foliated and sheared and, as a result, are commonly mineralized and altered. The unit is swarmed by quartz veins with a sugary texture, with oxidization and limonitization alterations and spread out vugges (based on stream sediment samples). The quartz-graphitic schist is also silicified, sericitized, chloritized and carbonatized (Fig. 7). There is also evidence for secondary mineralization which includes pyrite, chalcopyrite, sulphide vugges, carbonate 


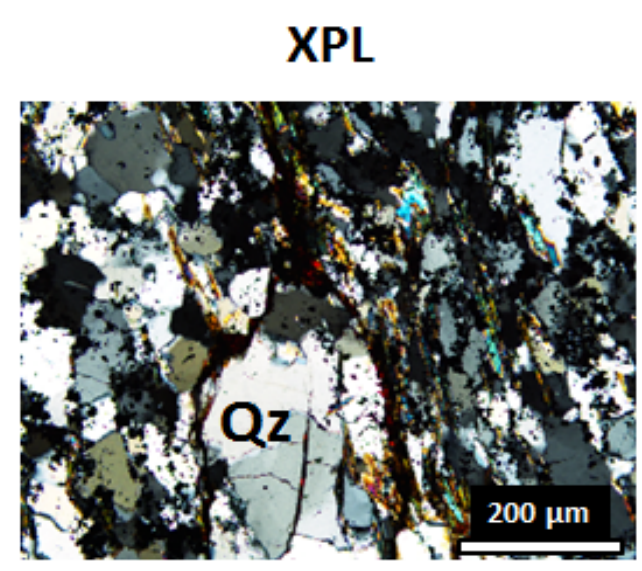

Refl

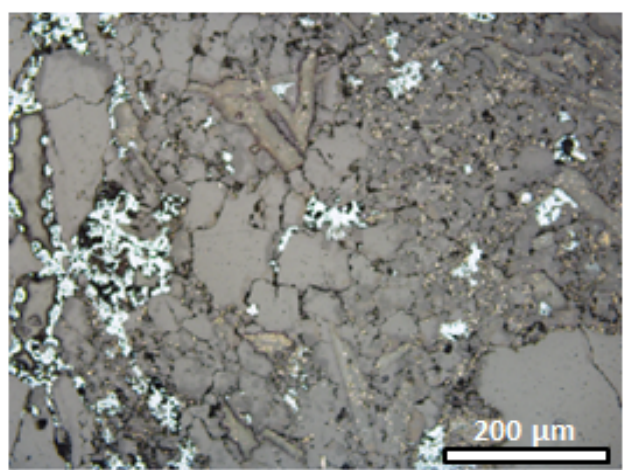

PPL

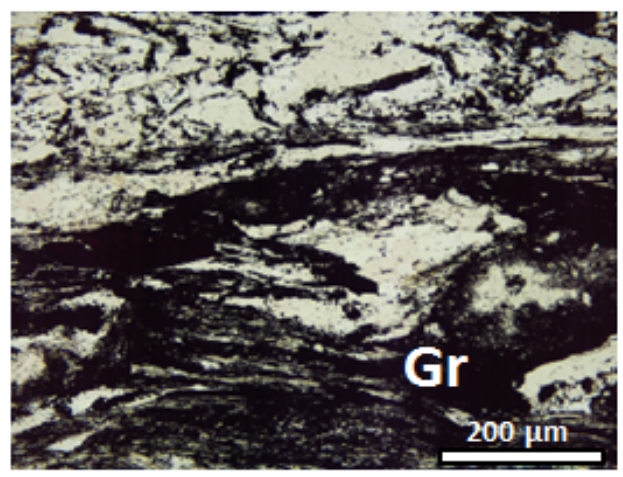

PPL

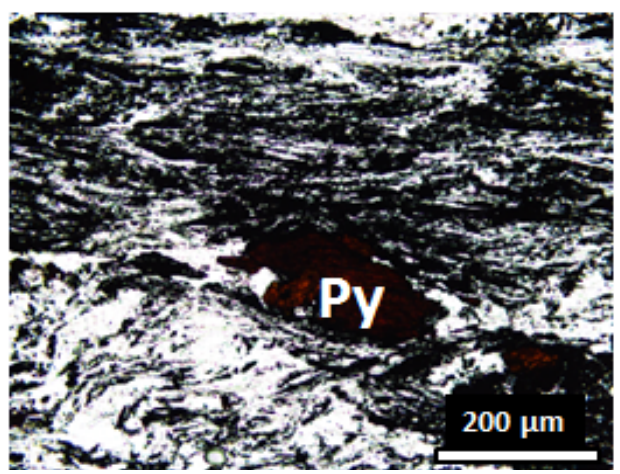

Fig. 7 Microscopic photographs of quartz-graphitic schist thin section samples, including cross-polarized light (XPL), PPL (plane polarized light) and Refl (reflective light) imagery. Quartz (Qz), carbonaceous material (Gr) and pyrite (Py) are highlighted in imagery.

(ankerite) and magnetite minerals in the unit (Fig. 4). Pitted trenches host high-grade graphite seams, with a width of a few meters to $>20 \mathrm{~m}$.

The unit is highly foliated in the strike of $\sim 10^{\circ}$ to $\sim$ $50^{\circ} \mathrm{N}$, with a dip of $\sim 40^{\circ}$ to $\sim 55^{\circ}$ toward west and east. It is also fractured across the foliation and brecciated. Brecciation is recognized by fragmented rocks cemented with finer materials such as silica and carbonates, and this is a common occurrence near the part of the shear zone or shear-affected lithologies. Lineations on the graphitic schist generally plunge to the north-north east. This may be related to thrusting movement activity within the region. Small-scale folds (mesofolds and kinkbands) are also observed in the graphitic schist.

\section{Petrography and Geochemistry}

The quartz-graphitic schist and other graphite-bearing units show a number of key microscopic features, identified from thin section observations (Fig. 7). Observations include various grades and flake sizes, with observed flake sizes of 2 $\mathrm{mm}, 1 \mathrm{~mm}, 250 \mu \mathrm{m}$ and $125 \mu \mathrm{m}$. Graphite occurrence across the sampled units commonly show a flaky or platy crystal form, of both regular and irregular habit. Crystals are typically 50-250 $\mu \mathrm{m}$ in length, with high reflectance. However, flakes up to $2 \mathrm{~mm}$ have been observed, and some units consist of smaller, more irregularly shaped crystals. Such textural variations may be the product of a variable and complex formation.

Observed microscopic mineralization includes the occurrence of quartz, graphite (occasionally showing isometric form), sericite, muscovite, biotite, various clay minerals, magnetite and occasional garnet. Secondary mineralization has also been observed, 
specifically pyrite, chalcopyrite, sphalerite, other sulfides and gold within the unit (Figs. 7-8). Gold often appears trapped within the carbonaceous matrix. Textures within samples include an apparent foliation carried by muscovite and graphite, $\mathrm{Y}$-intersections in quartz (also undulatory extinction), microscopic folding and crenulation cleavage. Samples analyzed include rock chip (and crush), stream sediment, heavy metal concentrates, soil and trench samples. The use
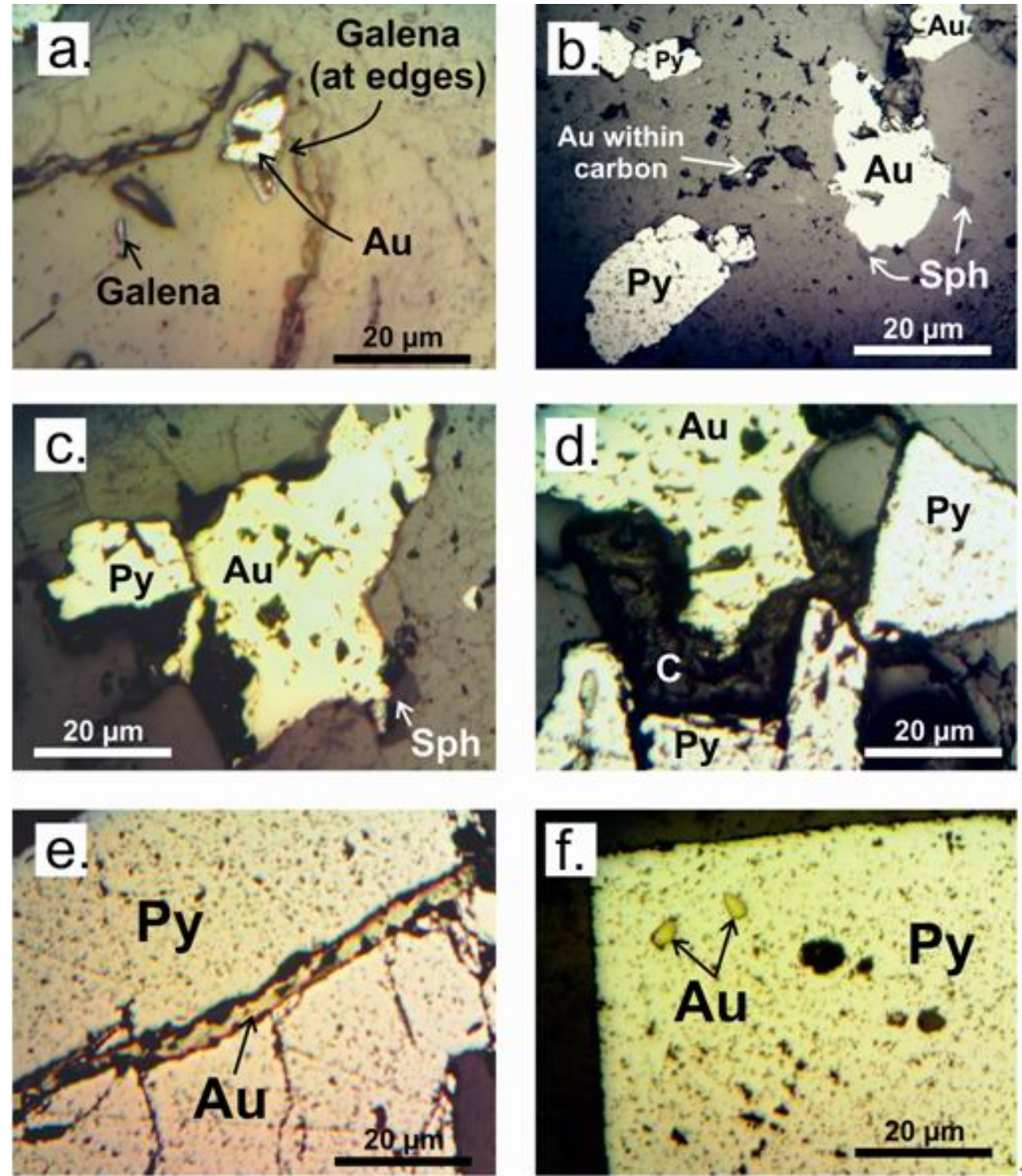

Fig. 8 Microscopic observations of gold and other alteration minerals in graphitic schist samples: (a) gold and galena, with galena replacing gold at the edges; (b) example of the regular occurrence of gold and pyrite, with sphalerite replacement at the edges of gold; (c) pyrite, gold and sphalerite; (d) gold and pyrite with interstitial carbon; (e) gold within vein of larger pyrite crystal; (f) gold inclusions within cubic pyrite crystal. Abbreviations: Au-gold; Sph-sphalerite; Py—pyrite; C-carbon. 
Table 2 Anomalous values in sampled graphitic units (stream sediment, rock chip and soil samples) in the Assosa study area as identified by Niton (handheld) XRF analysis.

\begin{tabular}{ll}
\hline \multicolumn{2}{l}{ Stream sediment samples } \\
\hline $\mathrm{Cu}$ & High 53-107 ppm \\
$\mathrm{As}$ & High 12.9-21 ppm \\
$\mathrm{Mo}$ & Low 1.22-4.21 ppm \\
\hline Rock chip samples & \\
\hline $\mathrm{Au}$ & High 6.55-10.2 ppm \\
$\mathrm{Ag}$ & High 60-182 ppm; Low 11-24 ppm \\
$\mathrm{Cu}$ & High 125-374 ppm \\
$\mathrm{As}$ & High 61-104 ppm \\
$\mathrm{Mo}$ & High 44.74-213.51 ppm \\
$\mathrm{Hg}$ & High 5 to 7 ppm \\
\hline Soil samples & \\
\hline $\mathrm{Au}$ & High 6-10.2 ppm \\
$\mathrm{Pb}$ & High 15-26.6 ppm \\
$\mathrm{As}$ & High 12-38.1 ppm \\
$\mathrm{W}$ & High 35-45.7 ppm \\
$\mathrm{Co}$ & High 500-2,720 ppm \\
$\mathrm{Ba}$ & High 1,017-2,320 ppm \\
$\mathrm{Sn}$ & $32.5-46.6 \mathrm{ppm}$ \\
\hline
\end{tabular}

and $240 \mathrm{ppb}$ from the upper Yohtse stream which drain from the quartz-graphitic schist. The composite anomalies and higher values in the northern area at the border of the concession could be related to the mineralization of the quartz veins hosted within the quartz-graphitic schist and alterations related to this unit. A number of anomalous values were identified by XRF analysis. The key findings are highlighted in Table 2.

Results obtained by AAS and XRF methods for rock chip, soil, heavy metal concentrates and trench samples show a number of anomalous groups of elements (including $\mathrm{Au}$ and associated pathfinders). These composite anomalies are from mineralized and altered quartz veins/veinlets, as well as within the quartz-graphitic schist. Results emphasize the presence of potentially economic gold within the graphite-bearing units.

\section{Beneficiation and Flotation}

From the initial $30 \mathrm{~g}$ sample, a dry concentrate of $10.5 \mathrm{~g}$ was achieved (Fig. 9). Initial trials indicate that high recovery of graphite is achievable - between $70-95 \%$. Due to the limitations of XRF and AAS for carbon analysis, the results have been largely based on visual identifications, yield and recovery trials and grade. The results indicate a high recovery using the floatation method.

Initial flake liberation and graphite concentrates show that flake sizes range from crystalline small flake to crystalline large flake, with a graphite concentrate from beneficiation of up to $70 \%$ and a yield potential of up to $95 \%$. The flakes range from coarse $>150 \mu \mathrm{m}$ to fine $<150 \mu \mathrm{m}$ (previously noted by petrographic observations; Fig. 8), and strong indications also show amorphous forms of $70 \mu \mathrm{m}$ microcrystalline material. Based on a production target recovery rather than the laboratory achieved figure, graphite recovery from fraction concentrate of $1 \mathrm{~mm}-500 \mu \mathrm{m}$ is $\sim 51 \%, 7.5 \%$ fraction mid and $5.1 \%$ from fraction tailings.

\section{X-Ray Diffraction}

Powdered X-ray diffraction provides a technique for identification of crystalline and amorphous components in a wide range of multi-component materials [27]. XRD (X-ray diffraction) has been
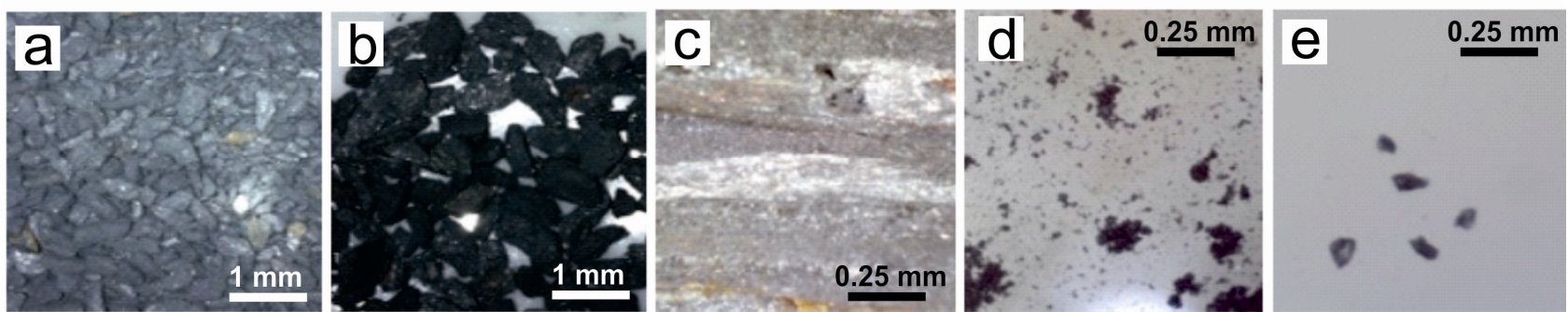

Fig. 9 (a) and (b) Various stages of bench top graphite beneficiation experimentation conducted; (c) macroscopic image of larger graphite flakes; (d) and (e) microscopic images of flakes with irregular crystal forms. 
applied to two graphitic samples from the study area. Samples selected for the study were "2GPC-97" and "2GPC-97 1K" (pre- and post-ashing preparation respectively). 2GPC-97 represents the quartz-graphitic schist with seemingly no $\mathrm{Au}$ (determined by AAS $=<$ $0.05 \mathrm{ppm}$ ), although XRF results and observations suggest otherwise.

Results presented (Fig. 10) reflect a whole rock composition; therefore, crystalline peaks will be diluted due to the heterogeneous nature of the samples. Common peaks and mineral phases overlap, resulting in more prominent peaks. For the 2GPC-97 sample (pre-ashing), as many as 15 peaks were identified. However, due to the heterogeneity of the samples (resulting in an increased background), these peaks cannot be quantified. As such, prominent peaks are treated qualitatively. Future work may be required, whereby phases are separated out, in order to better quantify the components.

The largest peak (highest intensity) is $26.2^{\circ}$, followed by observed but smaller peaks at $49.8^{\circ}, 59.6^{\circ}$, $68^{\circ}, 67.4^{\circ}$ and $26.6^{\circ}$. Several smaller but still
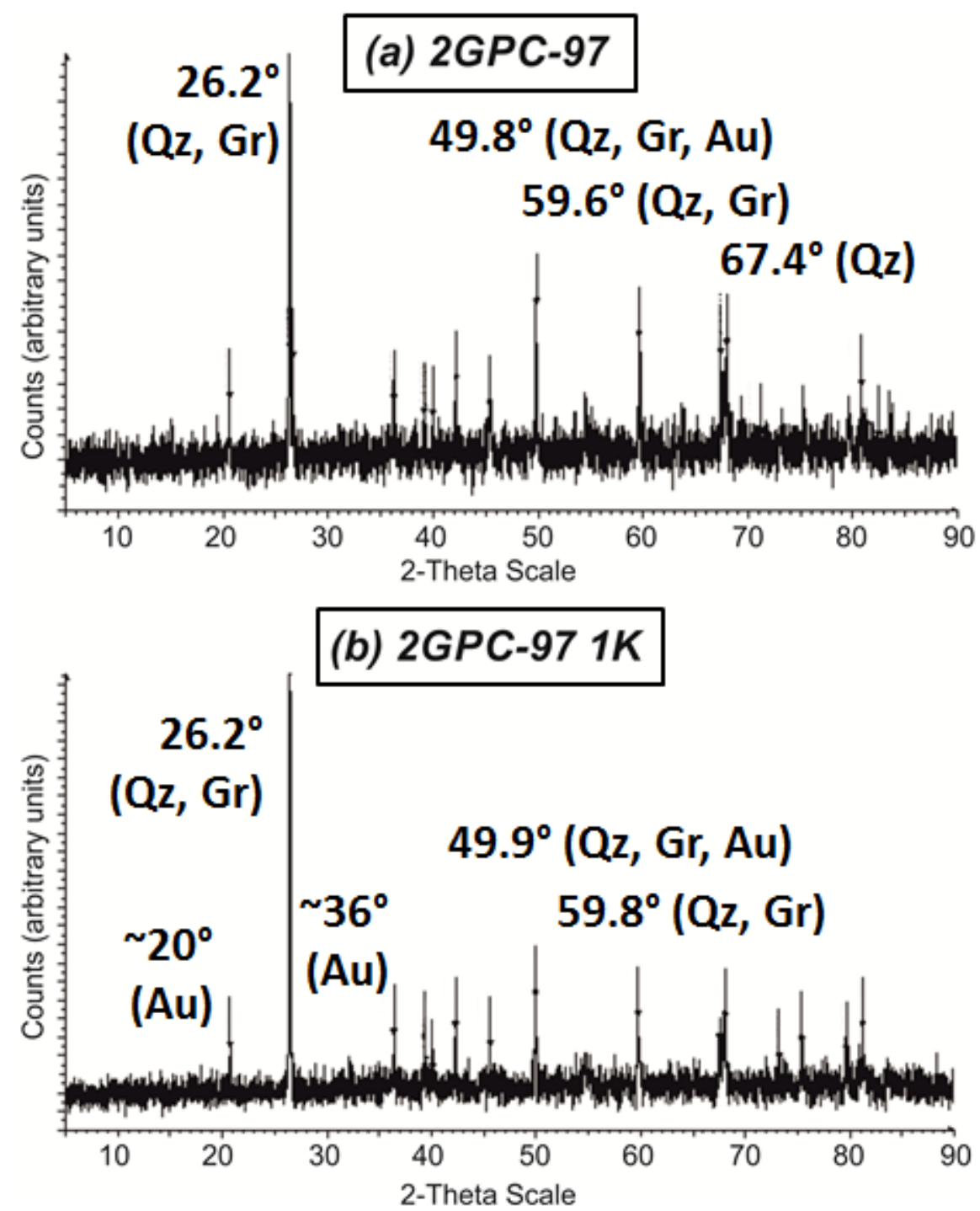

Fig. 10 (a) Pre-ashed 2GPC-97 graphitic sample XRD (X-ray diffraction) spectral response, with key peaks highlighted; (b) post-ashed 2GPC-97 sample XRD spectra. Both samples show typical quartz and graphite peaks, as well as smaller Au peaks (diluted following ashing procedure). 
identifiable peaks were also noted (identified by Bruker software and EVA program). The ashed 2GPC-97 1K sample shows slight variation in peak position, with 15 peaks again identified. The peak at $26.4^{\circ}$ is prominent, but, interestingly, the rest of the identified peaks are more diluted than the results of the non-ashed sample show. Other notable peaks include $49.9^{\circ}, 59.8^{\circ}$ and $68.1^{\circ}$, but these show a lower ntensity than pre-ashing sample. In order to act as a test of reliability, graphite and quartz (most common constituents) were input to EVA software for identification. Several graphite and quartz peaks were identified, including the most prominent peaks in 2GPC-97, both pre- and post-ashing (Figs. 10a and $10 \mathrm{~b}$, respectively). Main peaks correspond in part to quartz, including $26.2^{\circ}, 59.6^{\circ}, 68^{\circ}$ and $20.5^{\circ}$. Graphite also exhibits peaks at $26.2^{\circ}$ and $59.6^{\circ}$.

Quartz and graphite show slight overlap, which enhances the main peak. Numerous potential Au peaks were also identified. Several peaks correspond to compounds containing $\mathrm{Au}$ (identified by EVA software). These include gold compound peaks $\sim 26^{\circ}$, $\sim 36^{\circ}, \sim 43^{\circ}, \sim 50^{\circ}, \sim 60^{\circ}$ (Fig. 10), and with graphite and quartz also enhancing several peaks. It is beyond the purpose of this study to accurately identify the corresponding compounds associated with gold, though rough peak estimations suggest that gold may occur alongside $\mathrm{Ca}, \mathrm{Cs}, \mathrm{Nb}, \mathrm{Zr}, \mathrm{Eu}, \mathrm{Li}, \mathrm{Al}, \mathrm{Ge}$ or $\mathrm{Sn}$.

There are several potential Au peaks at $\sim 40^{\circ}$ and $\sim$ $20^{\circ}$ (akin to those of calcium gold examples), $\sim 42^{\circ}$ and $\sim 50^{\circ}$ (akin to AuEuSn examples), $\sim 33^{\circ}$ (AuEuGe), $\sim 40^{\circ}$ (aluminum gold), $\sim 37.5^{\circ}$ (gold zirconium), $\sim 42^{\circ}$ (copper gold tin), $\sim 39.5^{\circ}$ (lithium gold tin), $\sim 67^{\circ}$ (gold niobium), $\sim 39^{\circ}$ (gold copper), and $\sim 36^{\circ}$ (gold zirconium). As well as these instances, there are numerous strong peaks corresponding to the gold indium example of EVA.

In the ashed 2GPC-97 1K sample, graphite and quartz are again identified (with overlap for the prominent peak at $26.4^{\circ}$ ). Following ashing, fewer graphite peaks are noted, i.e., graphite has been lost due to the ashing procedure. Only three graphite peaks remain $\left(26.2^{\circ}, 59.8^{\circ}, 49.9^{\circ}\right.$ - both quartz and graphite) compared to up to four (i.e., not a significant change in spectral response). However, there is no significant loss of quartz, with peaks at $20.6^{\circ}, 36.3^{\circ}, 39.2^{\circ}, 67.5^{\circ}$ and $68.1^{\circ}$ identified.

These XRD results generally indicate a scattered, disordered response with numerous diluted peaks rather than individual, more prominent peaks. This is predominantly a result of sample heterogeneity, but may be further enhanced by the observed textural variations, with more than one type of particle occurrence (large, crystalline flakes and smaller, more irregular crystals). This likely relates to different processes of graphite formation within, and across, units. Other important findings of the initial XRD results are the identification and seemingly consistent qualitative peak occurrences of potential $\mathrm{Au}$ in the 2GPC-97 sample (previously thought to not contain any Au based on AAS).

Gold is present in pre- and post-ashing 2GPC-97 samples, but seemingly diluted with respect to graphite and quartz in the post-ashing sample- $\mathrm{Au}$ appears to be lower or lost due to sample preparations (possibly related to the occurrence of gold in the carbon matrix), which may account for low Au values by AAS analysis (though this is only speculated).

\section{Discussion and Conclusions}

The textural variations observed under microscope and by beneficiation, the spatial occurrence of graphite (within veins and in-situ within schists), and the enhanced scattered XRD response suggests that more than one population of graphite crystals exists across units (though XRD results may more readily reflect sample heterogeneity). These combined results may be the result of a progressive deformational setting (including both prograde and retrograde metamorphism), as indicated by the variable mineralogy across schist units and extensive deformational indicators in the region. This results in 
the observed change in physical properties and spatial occurrence of graphite in the sampled suite. It is suggested here that there were at least two graphite-forming events:

(1) The initial formation of earlier graphite resulting in variably crystalline graphite, forming in-situ within units at grades up to greenschist facies metamorphism (see Geological setting). Evidence for low- to high-temperature metamorphism in the area is cited in the metamorphic history and mineral paragenesis associated with the region. The sutures of former oceanic areas (the Arabian-Nubian Shield) consist of linear "schist belts" containing phyllitic to greenschist and/or lower amphibolite facies meta-sediments and meta-volcanics. Gold-bearing quartz-carbonate veins are associated with late- to post-tectonic calc-alkaline intrusions emplaced at the end of the Nabitah orogeny (680-650 Ma). The regional geology of the license area mapped is defined by Afa Domain Rocks, pre to syn tectonic granites, post tectonic granites and basalts. The alteration in the study area is observed to be associated with a second phase of deformation. These rocks have suffered from different types of tectonic activities and were extensively intruded by dioritic to granitic batholiths and plutons. Five major tectonic zones have been noted in western Ethiopia, three of which represent low grade volcano-sedimentary belts [18].

The study area is defined by alternating gneissic units and volcano-sedimentary sequences, interpreted as an imbricated basement-cover thrust-nappe complex, with Neoproterozoic deformation superimposed. Contacts between domains are not always exposed, but shear zones with high strain fabrics are noted, meaning contacts are interpreted in all cases to be tectonic. Such deformational history accounts for graphite forming in quartz-feldspar schists (greenschist to amphibolite grade), amphibolite schists (amphibolite grade) and up to quartz-graphitic schists (granulite grade facies).

(2) At a later stage, pre-formed graphite may have been dissolved (at high temperatures by decarbonatization reactions) and later remobilized. Following brittle deformation (forming fractures and resulting in graphite within brecciation zones) and fluid mobilization at lower grades, vein-type graphite (highly crystalline) is formed. This accounts for graphite occurrence within quartzite and pegmatite veins. These observations and interpretations are akin to those observed in the Aeacena Metamorphic Belt, Iberian Massif [4], with similarities to other notable examples, including occurrences in Sri Lanka, India and Madagascar [28-30].

Due to the unique physical and chemical properties and rarity of its occurrence, graphite is becoming an increasingly important economic resource due to its applications to high and green technologies. The identification of a new graphite occurrence and the extensive quartz-graphitic schist unit in the Assosa area is of significant interest due to the prospectivity potential of the graphite. Graphite appears to be a dominant feature on the northwestern boundary running through much of the southerly extent of the concession area. Graphite occurs over much of the area of interest 1 (AOI1), hosted by the aforementioned quartz-graphitic schist, but is also found within quartz-feldspar-mica schists and quartzites (as well as amphibolite, brecciation zones and pegmatitic-granitic bodies). There is evidence for mineralization and alteration in quartz-graphitic schist from field and petrographic observations, as well as a number of geochemical anomalies. Gold is a known component of the unit, and is widespread across the region. Flake sizes range from amorphous and crystalline small flake to coarse large flake $(>150$ $\mu \mathrm{m})$, with beneficiation of up to $70 \%$ and yield potential of up to $95 \%$. While AAS and XRF results may underestimate gold content of the quartz graphitic schist (due to the carbonaceous matrix and technique limitations), XRD results support the gold potential within the unit.

The two conventional methods of graphite mining 
are open pit and underground mining methods. As previously stated, natural graphite is classified as flake or microcrystalline graphite, macrocrystalline graphite, and vein or lump graphite. These types of graphite have distinct physical and chemical characteristics as a result of their occurrence in different geological settings. Flake graphite and macrocrystalline graphite are mined open pit and underground, whereas lump graphite is only mined underground. Due to the surface exposure and anticipated graphite classification, it is most likely that open pit mining would be the best method of operation in the Assosa region. This would involve overburden removal and the ore extracted directly. Drilling and blasting methods are commonly used on hard rock ore to liberate large-sized graphite flakes, following by crushing and grounding, before being subjected to flotation. The extracted graphite is brought to the surface mechanically or by hand picking, shoveling and cart, and finally moved to the plant for further processing.

This is the first documented occurrence of graphite in western Ethiopia. Graphite occurrence and graphite-bearing units are characterized by complex textural occurrences in a variably deformed region, hosted in a number of units, and the result of variable depositional settings. It is initially suggested that textural variations may be the product of (1) early in-situ formation during prograde metamorphism and (2) later vein-type mineralization during retrograde metamorphism. Graphite-bearing units also have a potentially significant accompanying gold content, which may have formed during mobilization of fluids also responsible for vein-type graphite. Graphite may form from medium greenschist facies, through amphibolite facies, up to granulite facies. Further information from exploration drilling would yield more information about the regional variation and mode of occurrence within the unit, particularly in regards to grade and flake size. However, this report uncovers just some of the potential of this deposit, particularly as gold forms a significant accompanying deposit in the graphite-bearing units.

\section{Acknowledgements}

Fieldwork and mapping was carried out by GP Resource Mining PLC in partnership with Tactical Environmental Response Ltd (TER). TER was responsible for the geochemical analysis, with the exception of XRD. The authors wish to greatly thank David Evans (XRD), Peter Greatbatch and David Wilde (thin sectioning) of Keele University. The authors also wish to thank the anonymous reviewers for manuscript feedback and comments.

\section{References}

[1] Luque, F. J., Pasteris, J. D., Wopenka, B., Rodas, M., and Barrenechea, J. F. 1998. "Natural Fluid-Deposited Graphite: Mineralogical Characteristics and Mechanisms of Formation." American Journal of Sciences 298: 471-98.

[2] Farquhar, J., Hauri, E., and Wang, J. 1999. "New Insights into Carbon Fluid Chemistry and Graphite Precipitation: Sims Analysis of Granulite Facies Graphite from Ponmudi, South India." Earth and Planetary Science Letters 171: 607-21.

[3] Winter, J. 2001. An Introduction to Igneous and Metamorphic Petrology. Prentice Hall, 697.

[4] Crespo, E., Luque, J., Fernández-Rodríguez, C., Rodas, M., Díaz-Azpiroz, M., Fernández-Caliani, J. C., and Barrenechea, J. F. 2004. "Significance of Graphite Occurrences in the Aracena Metamorphic Belt." Iberian Massif. Geological Magazine 14 (6): 687-97.

[5] Quinn, A. W., and Glass, H. D. 1958. "Rank of Coal and Metamorphic Grade of Rocks of the Narragansett Basin of Rhode Island.” Economic Geology 53: 563-76.

[6] Izawa, E. 1968. "Carbonaceous Matter in Some Metamorphic Rocks in Japan." Journal of the Geological Society of Japan 74: 427-32.

[7] Landis, C. A. 1970. "Graphitization of Dispersed Carbonaceous Material in Metamorphic Rocks." Contributions to Mineralogy and Petrology 4, 30 (1): 34-45.

[8] Beyssac, O., Rouzaud, J. N., Goffé, B., Brunet, F., and Chopin, C. 2002. "Graphitization in a High Pressure, Low-Temperature Metamorphic Gradient: A Raman Microspectroscopy and HRTEM Study." Contributions to Mineralogy and Petrology 143: 19-31. 
[9] Bény-Bassez, C., and Rouzaud, J. N. 1985. "Characterization of Carbonaceous Materials by Correlated Electron and Optical Microscopy and Raman Microspectroscopy." Scanning Electron Microscopy 119-32.

[10] Kribek, B., Hrabal, J., Landais, P., and Hladikova, J. 1994. "The Association of Poorly Ordered Graphite, Coke and Bitumens in Greenschist Facies Rocks of the Ponikla Group, Lugicum, Czech Republic: The Result of Graphitization of Various Types of Carbonaceous Matter." Journal of Metamorphic Geology 12: 493-503.

[11] Krauss, U. H., Schmidt, H. W., Taylor, H. A., and Sutphin, D. M. 1988. International Strategic Minerals Inventory Summary Report-Natural Graphite. U.S. Geological Survey Circular 930-H.

[12] Kutz, M., and Fackler, W. C. 2006. Mechanical Engineers' Handbook: Materials and Mechanical Design. 3rd ed.: DOI: 10.1002/0471777447.ch23.

[13] Northern Graphite Corporation/Industrial Minerals Magazine, 2011. Prices, Roskill Industry Report.

[14] Moores, S. 2014. Flake Graphite: Supply, Demand, Prices-GMP Securities. Simon Moores-Consultant/ Analyst at Benchmark Mineral Intelligence. Presentation on Flake Graphite Industry at GMP Securities Day in London, June 2014.

[15] Industrial Alliance Securities Inc. 2012. Graphite-Black Gold of the 21st Century. Sector Overview.

[16] Archer Exploration Limited Annual Report, 2011. Wayville, South Australia.

[17] Johnson, P. R., Andresen, A., Collins, A. S., Fowler, T. R., Fritz, H., Ghebreab, W., Kusky, T. M., and Stern, R. J. 2011. "Late Cryogenian-Ediacaran History of the Arabian-Nubian Shield: A Review of Depositional, Plutonic, Structural, and Tectonic Events in the Closing Stages of the Northern East African Orogen.” Journal of African Earth Sciences 61 (3): 167-232.

[18] Kazmin, V. 1973. Geological Map of Ethiopia 1: 2,000,000. Geological Survey of Ethiopia, Addis Ababa.

[19] Abraham, A., 1984. Geological Map of Gimbi Sheet (NC 36-12) 1:250,000. Preliminary Draft Compilation. Unpublished EIGS.

[20] Tefera, M., Chernet, T., and Haro, W. 1996. Geological map of Ethiopia, scale 1:2,000,000. Ethiopian Mapping
Authority, Ethiopia.

[21] Caracle Creek International Consulting Inc. 2013. Dul-Menghe and Agusha License Independent Technical Report. Benzu Gold Mining Ethiopia PLC.

[22] Allen, A., and Tadesse, G. 2003. "Geological Setting and Tectonic Subdivision of the Neoproterozoic Orogenic Belt of Tuludimtu, Western Ethiopia." Journal of African Earth Sciences 36 (4): 329-43.

[23] Tadesse, G., and Allen, A. 2004. "Geochemistry of Metavolcanics from the Neoproterozoic Tuludimtu Orogenic Belt, Western Ethiopia." Journal of African Earth Sciences 39 (3): 177-85.

[24] Juvonen, R., and Kontas, E. 1999. "Comparison of Three Analytical Methods in the Determination of Gold in Six Finnish Gold Ores, Including a Study on Sample Preparation and Sampling." Journal of Geochemical Exploration 65 (3): 219-29.

[25] Nude, P. M., Asigri, J. M., Yidana, S. M., Arhin, E., Foli, G., and Kutu, J. M. 2012. "Identifying Pathfinder elements for Gold in Multi-Element Soil Geochemical Data from the Wa-Lawra Belt, Northwest Ghana: A Multivariate Statistical Approach.” International Journal of Geosciences 3: 62-70.

[26] Ore Benefication. 2012. "Graphite Beneficiation and Extraction Method." Posted by ore Beneficiation on Jan. 23, 2012. http://orebeneficiation.wordpress.com.

[27] Ruland, W. 1964. "The Separation of Coherent and Incoherent Compton X-Ray Scattering." British Journal of Applied Physics 15: 1301-7.

[28] Katz, M. B. 1987. "Graphite Deposits of Sri Lanka: A Consequence of Granulite Facies Metamorphism." Mineralium Deposita 22: 18-25.

[29] Santosh, M., and Wada, H. 1993. "A Carbon Isotope Study of Graphites from the Kerala Khondalite Belt, Southern India: Evidence for $\mathrm{CO}_{2}$ Infiltration in Granulites." Journal of Geology 101: 643-51.

[30] Radhika, U. P., and Santosh, M. 1995. A Comparative Study of Graphite Occurrences in South India, Sri Lanka and Madagascar within East Gondwana. In India as a Fragment of East Gondwana. Edited by Yoshida, M., Santosh, M., and Rao, A. T., pp. 143-57. Gondwana Research Group Memoir No. 2. Field Science Publishers. 